\title{
Effect of the abrogation of TGF-B1 by antisense oligonucleotides on the expression of TGF-B-isoforms and their receptors I and II in isolated fibroblasts from keloid scars
}

\author{
GREGOR M. BRAN, ULRICH R. GOESSLER, CHRISTOPHER SCHARDT, \\ KARL HORMANN, FRANK RIEDEL and HANEEN SADICK
}

\begin{abstract}
Department of Otolaryngology, Head and Neck Surgery, University Hospital of Mannheim, University of Heidelberg, D-68135 Mannheim, Germany
\end{abstract}

Received December 29, 2009; Accepted February 25, 2010

DOI: 10.3892/ijmm_00000422

\begin{abstract}
Disequilibrium of dermal wound repair can result in continued accumulation of ECM and excessive scar formation. In susceptible genetically predisposed individuals, keloid formation can be observed. Keloid disease represents a benign dermal fibroproliferative tumor that is unique to humans. TGF- $\beta$ is known to play a key role in the pathogenesis of this disease which is still not fully understood. The isoforms TGF- $\beta 1$ and TGF- 32 have profibrotic properties, whereas TGF- $\beta 3$ may have antifibrotic functions. TGF- $\beta$ exerts its influence by binding to type I and type II TGF- $\beta$ receptors, thereby forming a complex and activating specific downstream effector molecules. The aim of this study was to investigate the effect of TGF- $\$ 1$ targeting by antisense oligonucleotides on the RNA synthesis and protein expression of TGF- $\beta$ isoforms and their receptors in keloid-derived fibroblasts. In tissue samples with normal fibroblasts (NFs) serving as control samples, expression of TGF- $\beta 1$ and $-\beta 2$ was decreased when compared to keloid fibroblasts (KFs), while expression of TGF- 33 and of TGF-BRII was significantly higher in NFs. In the ELISA assay, abrogation of TGF- $\beta 1$ led to a significant decrease in TGF- $\beta 1$ and $-\beta 2(\mathrm{p}<0.05)$. Expression of TGF- 32 mRNA was reduced. Expression of TGF-B3 mRNA revealed contrary patterns in KFs from different patients while expression of TGF-ßRI was found to be equal during the measurement period. TGF-ßRII mRNA expression was increased after 48 and $72 \mathrm{~h}$ respectively. There is growing evidence for a regulatory mechanism between TGF- $\beta 1$ and its receptors. Our findings support this theory by suggesting interrelations between the different TGF- $\beta$ isoforms and their receptors. Abnormal response of KFs to
\end{abstract}

Correspondence to: Dr Gregor M. Bran, Department of Otolaryngology, Head and Neck Surgery, University Hospital of Mannheim, Theodor-Kutzer-Ufer 1-3, D-68167 Mannheim, Germany

E-mail: gregor.bran@umm.de

Key words: transforming growth factor- $\beta$ isoform, transforming growth factor- $\beta$ receptor, antisense, fibroblast, keloid
TGF- $\beta$ might reflect a modification in the regulatory pathway that occurs at the receptor level or during intracellular transduction. Improving the understanding of TGF- $\beta$ in keloid disease could lead to the development of clinically useful therapeutic modalities for treatment of keloid disease or even allow identification of preventive strategies.

\section{Introduction}

The basic composition of tissue can be described as cells surrounded by extracellular matrix (ECM). Injury of cells or the matrix leads to an instant reaction within any healthy organism with resident and inflammatory cells releasing different cytokines that stimulate cell division and the production of new ECM. In case of physiological wound healing, these spatiotemporally highly orchestrated processes are terminated once tissue integrity and physiological function have been restored. However, in case of disequilibrium of reparative reactions, failure to halt repair processes can result in continued accumulation of ECM, impairing morphology and function of tissue, and ultimately resulting in fibrotic disease causing organ failure. Derangement of dermal wound repair can either lead to chronic ulcerative wounds or result in excessive scar formation, which is believed to be the dermal equivalent of fibroproliferative disorders. In susceptible genetically predisposed individuals, keloid formation can be observed after minimal skin trauma as a consequence of an abnormal response to wounding. Keloid disease represents a benign dermal fibroproliferative tumor that is unique to humans (1).

Keloids contain atypical fibroblasts with an overabundance of ECM components, particularly with an excessive deposition of collagen in the dermis and subcutaneous tissue. They grow invasively into the surrounding healthy skin and are not confined to the border of the initial wound. They seldom show a tendency to regress spontaneously (2-4). The prevalence between the male and female gender is equally distributed. It has been estimated that keloids most frequently occur in 15-20\% of Blacks, Hispanic and Asians and less commonly in Caucasians. To date, no keloid formation has been described in albinos $(2,5,6)$. There appears to be a genetic predisposition to keloid formation in darker skinned individuals, but also positive family history is discussed. 
However, no specific gene has been linked to the development of keloids to date (7).

Apart from pain and pruritus, functional deficit, restriction of tissue movement, potential risk of uncontrolled growth, and the cosmetic burden, which is very often accompanied by adverse psychological effects, illustrate the prevailing challenges for every facial plastic surgeon. The exact pathogenesis of keloids remains poorly understood, and the broad variety of conservative, surgical and even experimental therapeutic approaches represent its status as an enigma. Surgical excision with intralesional steroid injection is a standard method of treatment. However, recurrence is commonly observed after surgical excision often exacerbating the primary condition (8).

Evidence suggests that transforming growth factor $\beta$ (TGF-B) plays a key role as a cytokine by initiating and terminating tissue repair and whose sustained production underlies the development of fibrosis (9). TGF- $\beta$ was first discovered in 1983 by virtue of its ability to transform the phenotype of mesenchymal cells, supporting anchorage independent growth of colonies in soft agar (10). Since then TGF- $\beta$ has been recognized as a potent family of cytokines involved in cellular growth and differentiation, angiogenesis, adhesion, chemotaxis and ECM metabolism $(11,12)$.

Three mammalian isoforms, designated as TGF- $\beta 1$, TGF- 32 , and TGF-B3 have been described, all being expressed during physiological wound healing of the skin. TGF- $\beta 1$ and $-\beta 2$ are thought to have profibrotic properties, whereas TGF- $\$ 3$ may have antifibrotic functions $(2,3,13)$. TGF- $\beta$ exerts its influence by binding to type I and type II TGF- $\beta$ receptors (TGF- $ß R I$ and TGF-BRII). The binding of the ligand to TGF-BRII seems to mediate the formation of a heteromeric complex of TGF- $\beta$ receptors I and II, thereby activating specific downstream effector molecules $(4,14)$ (Fig. 1).

TGF- $\beta$ stimulates growth and collagen secretion, and there is an emerging consensus that these isoforms are important mediators in keloid pathogenesis. Increased levels of TGF- $\beta$ have been demonstrated in keloid tissues with higher expression levels for TGF- $\beta 1$ and $-\beta 2$ than in normal human dermal fibroblasts (11). Furthermore, it has been observed, that keloid fibroblasts showed a marked sensitivity to TGF- $\beta$. Treatment with TGF- $\beta 1$ results in an increase in fibronectin biosynthesis leading to an overproduction of ECM components in keloid fibroblasts $(3,9)$. In addition, TGF- 11 treatment upregulates collagen production, and keloid fibroblasts show a greater proliferative capacity than normal human dermal fibroblasts $(3,15,16)$.

In light of these data we are beginning to realize that the key to understand the pathogenesis of keloid formation may rest on understanding the expression, activation and interaction between these TGF- $\beta$ isoforms and the TGF- $\beta$ receptors. The marked properties of TGF- $B$ within keloids suggest an altered response of keloid fibroblasts to TGF- $\beta$ ligands or a change that occurs at the receptor level. Investigating the interrelationship between the isoforms and their receptors might therefore contribute to our knowledge of keloid pathogenesis.

The aim of this study was to investigate the effect of TGF- $\beta 1$ targeting by antisense oligonucleotides on RNA synthesis and protein expression of TGF- $B$ isoforms and the specific receptors TGF- $\beta$ type I and type II in keloid-derived fibroblasts.

\section{Materials and methods}

Immunohistochemistry. Informed consent was obtained from all individual subjects for all procedures. The selection of patients by classifying human fibroproliferative scars as keloids was performed by two facial plastic surgeons undergoing the reconstructive procedure. Fresh tissue specimens for dermal fibroblast cultures were obtained from 5 healthy patients with keloids (4 keloids formed after initial otoplasty and one after tympanoplasty) during reconstructive surgery performed at the Department of Otolaryngology, Head and Neck Surgery, University Hospital of Mannheim. The study was approved by the Ethics Committee of the University Hospital of Mannheim, and written consent was obtained from all subjects. Healthy skin specimen were obtained from adjacent normal dermis during keloid excisions from the same patients. A small probe of each resected scar was sent to the pathology laboratory for histologic processing and confirmation of the clinical diagnosis. Samples were frozen in liquid nitrogen for TGF- $\beta$ isoforms and TGF- $\beta$ receptor I and II identification. For in vitro analysis dermal fibroblasts isolated from keloids and normal controls were cultured in Falcon Petri dishes (Greiner, Germany) at $37^{\circ} \mathrm{C}$ in a $5 \% \mathrm{CO}_{2}$ fully humidified atmosphere in serum-free Fibroblast Growth Medium (PromoCell, Heidelberg, Germany) supplemented with antibiotics [Life Technologies, Inc. (Gibco BRL), Gainthersburg, MD, USA]. The immunohistochemistry for TGF- $\beta 1,-\beta 2,-\beta 3$ and the TGF- $\beta R I$ and $-\beta R I I$ was performed using the streptavidin-biotin complex procedure. Endogenous peroxidase was blocked with $0.3 \%$ hydrogen peroxidase for $30 \mathrm{~min}$. Sections were washed with phosphate-buffered saline (PBS) and incubated with normal rabbit serum in PBS for $30 \mathrm{~min}$ at room temperature in order to block non-specific antibody reaction. The sections were then incubated overnight at $4^{\circ} \mathrm{C}$ with the primary antibody. The slides were washed in several changes of PBS. The sections were then incubated with a peroxidase-conjugated secondary antibody (Dako, Hamburg, Germany). After being washed twice in PBS, the sections were treated with a streptavidin-biotin-peroxidase complex, and peroxidase reaction was performed using diaminobenzidine (DAB) (Dako) as chromogen. Different antibodies were diluted to the desired concentrations in PBS. Controls were carried out by omitting the primary antibody. Light microscopic investigation was performed using a Zeiss Axiophot microscope (Zeiss, Oberkochen, Germany).

Oligodeoxynucleotides. Phosphorithiotated 14-mer oligodeoxynucleotides (ODNs) were synthesised on an Applied Biosystems 394 DNA synthesiser (Applied Biosystems Inc. Forster City, CA, USA) by means of B-cyanothylphosphoramidite chemistry to minimize degradation by endogenous nucleases. The antisense oligonucleotide (5'-CGA TAG TCT TGC AG-3') was directed against the translation start site and surrounding nucleotides of the human TGF- 31 cDNA. The in vitro inhibitory effect of these antisense ODNs on TGF- $\beta 1$ expression at both the mRNA and protein levels in human cells was previously described (17). All 


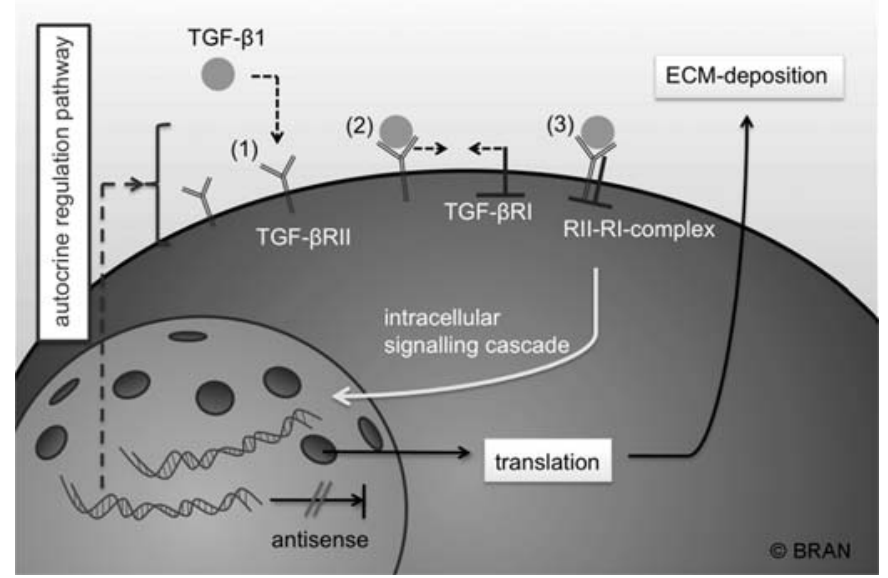

Figure 1. TGF- $\beta 1$ binds to TGF-ßRII. Once the ligand is bound, TGF- $\beta$ RII binds to TGF-BRI forming a complex and thereby initiating a transduction of downstream signals which ultimately stimulate the accumulation of matrix components and the transcription of genes affecting almost all phases of the wound healing process. The dashed arrow on the right indicates a potential regulation between TGF- $\beta 1$ and its receptors in an autocrine fashion.

experiments were performed with $3 \mu \mathrm{M}$ ODNs. To determine the effect of oligonucleotides on the expression of the TGF- $\beta$ isoform mRNA or the receptor mRNA, fibroblasts were plated at a density of $10^{5}$ cells/microtiter well in 24-well polystyrene plates (Falcon). After $24 \mathrm{~h}$, the cells were rinsed twice with medium, and fresh TGF- $\beta 1$ oligo medium containing antisense ODNs was added followed by an incubation period of 48 and $72 \mathrm{~h}$.

Cytokine immunoassay. Cell culture supernatants were collected in sterile tubes and stored at $-20^{\circ} \mathrm{C}$ until use. The cytokine concentrations (TGF- $\beta 1,-\beta 2,-\beta 3$ ) were then determined by an ELISA technique (R\&D Systems, Wiesbaden, Germany). The system used a solid-phase monoclonal antibody and an enzyme-linked polyclonal antibody raised against the recombinant cytokines. According to the manufacturer's guidelines, each ELISA assay measured $100 \mu \mathrm{m}$ of supernatant. All analyses and calibrations were carried out in duplicate. The calibrations on each microtiter plate included recombinant human cytokine standards provided in the kit. All concentrations were documented as $\mathrm{ng} / \mathrm{ml}$. The Student's t-test was used to calculate p-values. Differences were considered to be of statistical significance when $\mathrm{p}$-values were $<0.05$. The SPSS software package for Windows was used to perform all statistical analyses.

$R T-P C R$. To isolate the RNA from the fibroblasts grown in monolayer, the cells were directly lysed in the culture dish by the addition of $1 \mathrm{ml}$ RNA-Clean (RNA-Clean System, AGS, Heidelberg, Germany). After addition of $0.2 \mathrm{ml}$ chloroform per $2 \mathrm{ml}$ of homogenate and centrifugation for $15 \mathrm{~min}$ at $12,000 \mathrm{x} \mathrm{g}\left(4^{\circ} \mathrm{C}\right)$, the supernatant was removed from the RNA precipitate. The RNA pellet was washed twice with $70 \%$ ethanol by vortexing and subsequent centrifugation for $8 \mathrm{~min}$ at 7,500 $\mathrm{x} \mathrm{g}\left(4^{\circ} \mathrm{C}\right)$. After drying the RNA pellet, it was dissolved in DEPC water. The RNA was reverse transcribed (StrataScript First-Strand Synthesis System, Stratagene, La
Jolla, CA, USA) into cDNA using random-oligonucleotide primers. Primer sequences used for RT-PCR were as follows: TGF-31: 5'-TGG CGA TAC CTC AGC AAC C-3' and 5'-CTC GTG GAT CCA CTT CCA G-3'; for TGF-B2: 5'-ATC CCG CCC ACT TTC TAC AGA C-3' and 5'-CAT CCA AAG CAC GCT TCT TCC G-3'; for TGF-33: 5'-TAC TAT GCC AAC TTC TGC TCA G-3' and 5'-AAC TTA CCA TCC CTT TCC TC-3'; for TGF-ßRI: 5'-ACG GCG TTA CAG TGT TCT G-3' and 5'-GGT GTG GCA GAT ATA GAC C-3'; for TGF-ßRII: 5'-AGC AAC TGC AGC ATC ACC TC-3' and 5'-TGA TGT CTG AGA TGT CC-3' (GenBank $\left.{ }^{\mathrm{TM}}\right)$.

TGF- $\beta$ isoform and receptor mRNA levels were measured in all cell types using RT-PCR (MMP-CytoXpress Multiplex PCR Kit, Bio Source, San Francisco, CA, USA) according to the manufacturer's instruction manual. To fractionate the MPCR DNA products, the MPCR products were mixed with $6 \mathrm{X}$ loading buffer and separated on a $2 \%$ agarose gel containing $0.5 \mathrm{mg} / \mathrm{ml}$ ethidium bromide, visualized with UV light and recorded using a CCD camera. To test the quality of the cDNA, the kit includes primers for GAPDH. Results were obtained for two independent experiments.

\section{Results}

The immunohistochemical investigation using antibodies directed against TGF- $\beta 1,-\beta 2,-\beta 3$, TGF- $\beta R I$, and - $\beta$ RII demonstrated a decreased expression of TGF- $\beta 1$ and $-\beta 2$ protein in normal fibroblast (NF) monolayers cultured from tissue samples from healthy skin compared to keloid fibroblast (KF) monolayer cultures after performed keloid scar resection. The expression of TGF-B3 was significantly higher in the NFs. Immunohistochemical analysis of TGF-ßRI and -ßRII demonstrated no changes between the NFs and KFs concerning the type I receptor, whereas the expression of TGF-BRII was increased in the NFs. Representative examples of staining are shown in Fig. 2.

To quantitate the cytokine secretion to the supernatant of keloid-derived fibroblasts, an ELISA assay was performed after 48 and $72 \mathrm{~h}$, respectively. TGF- $\beta 1,-\beta 2$ and $-\beta 3$ were detectable in the supernatant of the keloid fibroblast cell line. In the supernatants the treatment of KFs with $3 \mu \mathrm{M}$ TGF- $\beta 1$ antisense ODNs for 48 and $72 \mathrm{~h}$ resulted in a significant decrease in expression of TGF- $\beta 1$ and $-\beta 2(p<0.05)$. Abrogation of TGF- $\beta 1$ also showed a tendency to downregulate the secretion of TGF- $\beta 3$ after $48 \mathrm{~h}$ of incubation time. After $72 \mathrm{~h}$, a tendency to up-regulate the secretion of TGF-B3 was observed. These trends showed no statistical significance (Fig. 3).

The described changes were also demonstrated after immunohistochemical investigation. Treatment with TGF- 1 antisense ODNs revealed an increased expression of the TGF-ßRII after 48 and $72 \mathrm{~h}$. Expression of TGF-ßRI did not change after incubation with the antisense (Fig. 4).

After treatment of KFs with TGF- 31 antisense ODNs in vitro, expression of the mRNA of TGF- $\beta 1,-\beta 2,-\beta 3$, TGF-ßRI and - ßRII was measured using the multiplex RTPCR kit. Incubation time was 48 and $72 \mathrm{~h}$, respectively, containing $3 \mu \mathrm{M}$ of TGF- $\beta 1$ antisense ODNs. Expression of TGF- 32 mRNA was reduced by antisense treatment. Expression of TGF- 33 mRNA revealed contrary expression 

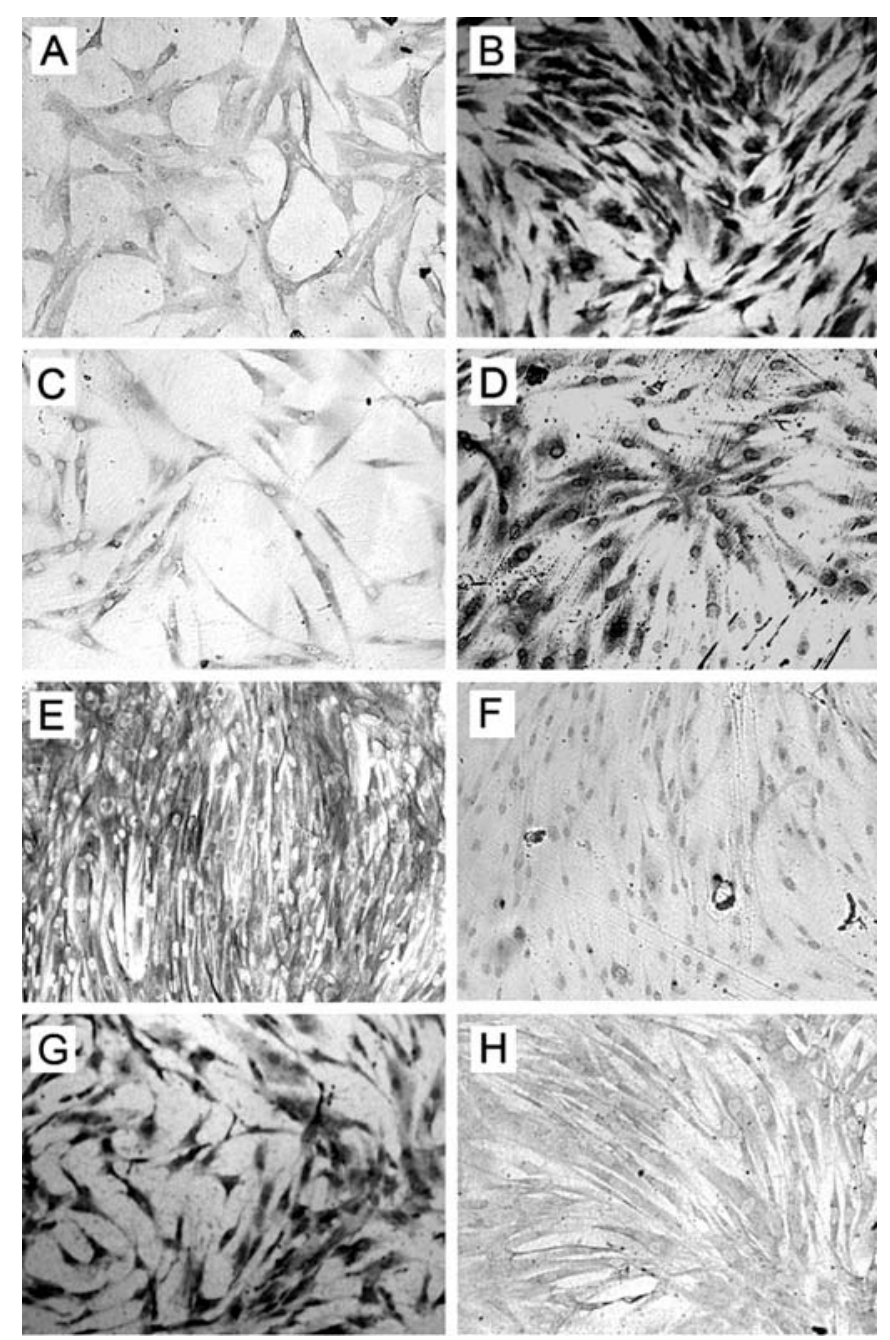

Figure 2. Immunohistochemical investigation of tissue samples from normal skin (NFs, left) and keloid scars (KFs, right). Expression patterns of (A and B) TGF- $\beta 1,(C$ and D) TGF- 32 , (E and F) TGF- 33 and ( $G$ and $H)$ TGF-ßRII.

patterns in KFs from different patients. Expression of TGF-ßRI was found to be equal during the measurement period. TGF-ßRII mRNA expression was increased after 48 and $72 \mathrm{~h}$, respectively (Fig. 5).

\section{Discussion}

The ability of TGF- $\beta$ to act as a mitogen for fibroblasts and to stimulate ECM deposition is well known. This growth factor is known to cause accumulation of matrix components by enhancing fibronectin and proteoglycan synthesis while reducing matrix degradation by reducing collagenase production by increasing the production of collagenase inhibitors $(1,18,19)$. Excessive scarring secondary to excessive production of ECM is the characteristic of fibrotic disease. Keloid formation can be considered to be the dermal equivalent to fibroproliferative diseases such as pulmonary fibrosis, hepatic cirrhosis and glomerulonephritis (9,20-23).

Younai and co-researchers demonstrated a unique oversensitivity of KFs to TGF- $\beta$, exhibiting an exaggerated response to this cytokine in comparison to fibroblasts from hypertrophic scars (24). Bettinger et al also found a


Figure 3. To quantitate cytokine secretion an ELISA assay was performed 48 and $72 \mathrm{~h}$ after treatment with TGF- 31 antisense ODNs $\left({ }^{*} \mathrm{p}<0.05\right)$.

significant increase in the response rate to TGF- $\beta$ in KFs, with an increase in fibroblast proliferation and collagen synthesis (15). Increased rates of proliferation and collagen synthesis suggest an altered response of KFs to this cytokine, which might reflect a modification in the regulatory pathway that occurs at the receptor level or during intracellular transduction $(4,9)$. According to the literature, TGF- $\beta 1$ and $-\beta 2$ mRNA expression was found to be higher in KFs than in NFs or hypertrophic scar fibroblasts, whereas TGF- 33 mRNA expression was significantly lower $(3,11,25)$. Our results are consistent with these findings. Our data showed that TGF- $\beta 1$ and $-\$ 2$ expression was significantly increased in cultured KFs in comparison to NF monolayers. Expression of TGF-B3 was found to be higher in NFs in comparison to KFs (Fig.1). The low expression of TGF-B3 in KFs might reflect an important characteristic of the aberrant normal wound healing response which could contribute to the uncontrolled fibrotic reaction, but it could also be a reason for the tendency of keloids to grow invasively. Shah et al demonstrated that scar formation was reduced after external application of a TGF- $\beta$ neutralizing antibody, providing evidence that manipulation of this central cytokine could inhibit scarring (26).

Among the three isoforms of TGF- $\beta$, TGF- $\beta 1$ is considered to be the key mediator in the pathogenesis of keloid formation (11).

TGF- $\beta$ exerts its biological effects on its target cells by interacting with the specific transmembrane TGF- $\beta$ receptors. 

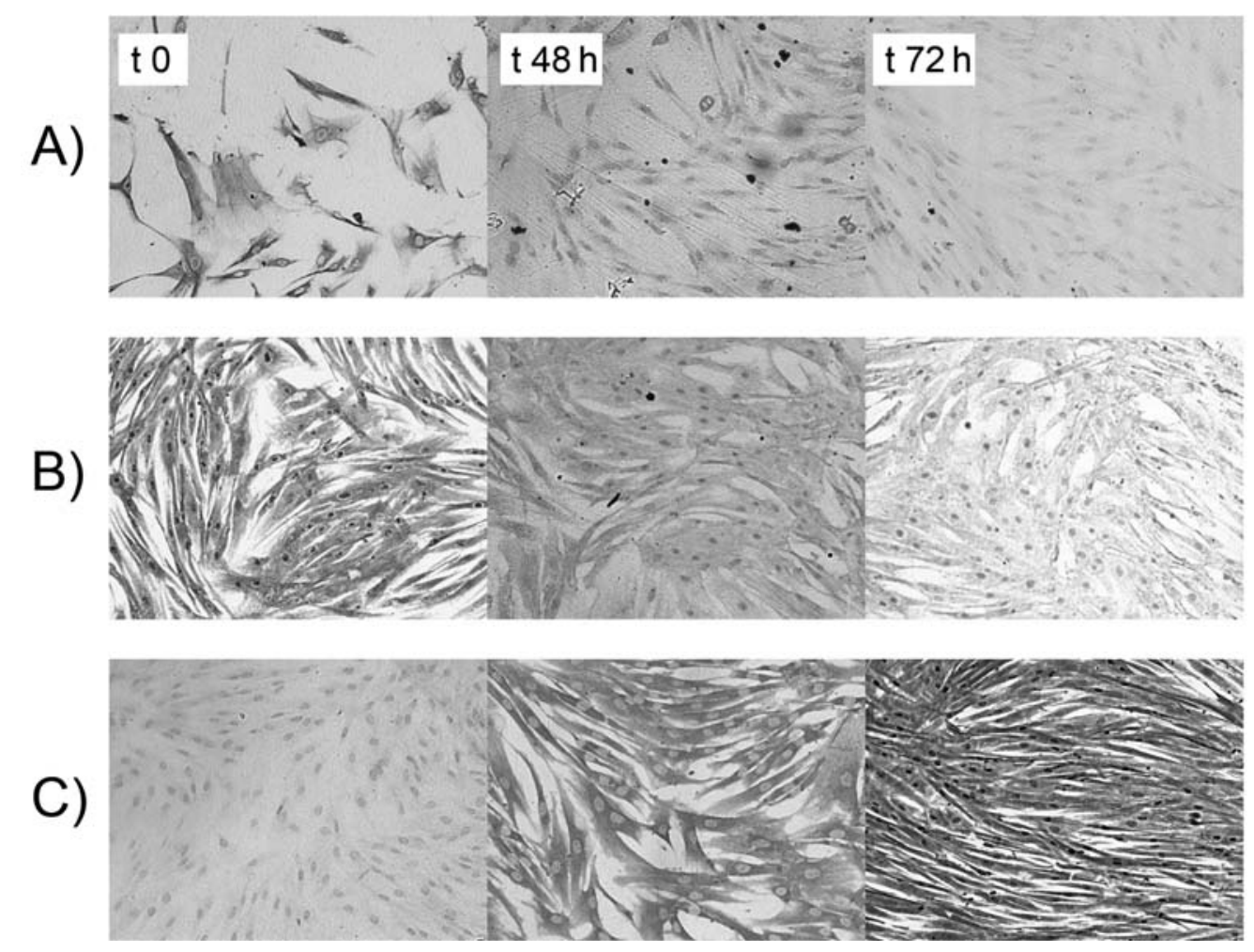

Figure 4. Immunohistochemical staining of KFs at t0, $48 \mathrm{~h}$ and $72 \mathrm{~h}$ after treatment with TGF- $\beta 1$ antisense ODNs. Expression pattern of (A) TGF- 31 , (B) TGF- 32 and (C) TGF-ßRII.

$\mathbf{A}$

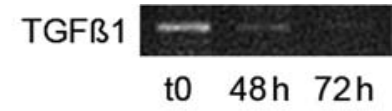

B

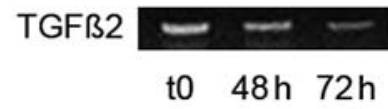

C

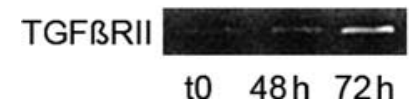

Figure 5. Expression of mRNA in KFs before (t0), after $48 \mathrm{~h}$ and after $72 \mathrm{~h}$ of treatment with TGF- $B 1$ antisense ODNs. Expression of (A) TGF- $B 1$ mRNA, (B) TGF-B2 mRNA and (C) TGF-BRII mRNA.

Type I and II are the most active receptors involved directly with this signal transduction (27). TGF-ßRI is involved in the initial ligand binding. Once the ligand is bound, the TGF-ßRII binds to the TGF-ßRI forming a complex and thereby initiating a transduction of downstream signals which ultimately stimulate the transcription of genes which can affect almost all phases of the wound healing process (28). Tissue fibrosis is considered to arise due to the failure of termination of the physiological wound healing response (29).

Bock et al showed elevated levels of mRNA expression of TGF-ßRI in keloids, whereas TGF-ßRII was significantly decreased in KFs (3). Goldberg et al showed that overexpression of TGF-BRII led to the inhibition of fibroblast proliferation (30). However, Chin et al found increased expression of TGF- $\beta$ RI and - $\beta$ RII in keloids. At later stages an increase in TGF-BRII expression may lead to decreased keloid activity and progression in size (4). Yamamoto et al demonstrated that adenovirus-mediated overexpression of a truncated TGF- $\beta$ receptor efficiently blocked TGF- $\beta$ signaling and subsequently abrogated its diverse effect (31). Chu and co-researchers showed that treatment with a novel truncated TGF-BRII downregulated collagen synthesis, inhibited cell growth and reduced TGF- $\beta 1$ secretion in KFs (32).

These findings support the hypothesis that two major strategies can be employed to block TGF- $\beta$ signal transduction for the treatment of keloid scars. The first one is to reduce the active form of TGF- $\beta$. One potential method is to apply antisense TGF- $\beta$ oligonucleotides in the process of wound healing. The second strategy is to increase soluble TGF-ßRII $(12,26,31,32)$.

We investigated the effect of the abrogation of the key mediator, active TGF- $\beta 1$, on the expression of the other TGF- $\beta$ isoforms and TGF- $\beta R I$ and TGF- $\beta$ RII.

The treatment of KF monolayers with TGF- $\beta 1$ antisense ODNs led to a significant reduction in TGF- $\beta 1$ and $-\beta 2$ after 48 and $72 \mathrm{~h}$, respectively. We observed that the mRNA expression of TGF-B3 was initially reduced but showed a tendency for increased expression patterns after $72 \mathrm{~h}$. These findings support the hypothesis of the possible therapeutic potential of a TGF- $\beta 1$-oriented antisense therapy. Furthermore, they seem to indicate a key role of this cytokine in keloid pathogenesis. A reduction in both profibrotic isoforms may lead to decreased keloid activity and growth. The observed tendency of TGF-B3 up-regulation also supports this hypothesis. However, expression of TGF- $B 3$ mRNA was 
different due to the initially heterogeneous resections of keloid tissue samples. The differences in results and the tendencies observed in the expression of TGF- 33 mRNA might be attributed to alternate maturity and clinical stages of the keloids which were taken for biopsies. Comparing the published data we can also find partly inconsistent results. Varying data might again be the result of the clinical heterogeneity of the investigated keloid tissue samples or the result of different methods applied for analysis. Apart from the correct clinical and histopathological diagnosis of keloid tissue, the relevance of the biopsy site remains unexplained.

Bock et al (3) showed a decrease in TGF-ßII mRNA expression after in vitro stimulation of KFs with TGF-ß1. In the present study abrogation of TGF- $\beta 1$ clearly increased the expression of TGF- $\beta$ RII at the mRNA and protein levels, whereas no changes in expression patterns were observed for TGF-ßRI. As discussed by Centrella and Bock (33), the ratio of type I to type II receptor may determine the biological effect of TGF- $\beta$ on the proliferation and target gene expression. In support of a role of TGF- $\beta$ receptors in keloid pathogenesis, we found that the ratio of TGF- $31 / \mathrm{TGF}-\beta \mathrm{II}$ mRNA expression was significantly decreased after abrogation of TGF- $\beta 1$ in KFs. These findings suggest a regulation between TGF- $\beta 1$ and its receptors. There is growing evidence for a regulatory mechanism between TGF- 11 and TGF-BRI and TGF-BRII in an autocrine fashion $(3,34)$. Bock et al theorized that cytokines alone do not induce fibrosis, but it is more likely that a certain combination of TGFs and their receptors may lead to increased ECM synthesis. Our findings support this theory by suggesting interrelations between the different TGF- $\beta$ isoforms and their specific receptors (Fig. 1).

An abnormal response of the KFs by means of an altered TGF- $\beta$ pathway could be a central element in understanding this fibrotic process. Increased understanding of the role of TGF- $\beta$ in keloid disease will, not only enable us to devise strategies for the development of clinically useful therapeutic modalties, but more importantly will also help us to shed light on the basis of biomolecular mechanisms involved in the pathogenesis of this disease in order to identify effective preventive strategies for predisposed patients.

We believe that the approach initiated represents important analytic potential which requires further exploration by all who are interested in deciphering this difficult to treat disorder.

\section{Acknowledgements}

The authors would like to thank Petra Prohaska, Department of Otorhinolaryngology, Mannheim, for her excellent technical assistance.

\section{References}

1. Tuan TL and Nichter LS: The molecular basis of keloid and hypertrophic scar formation. Mol Med Today 4: 19-24, 1998.

2. Bran GM, Goessler UR, Hormann K, Riedel F and Sadick H: Keloids: current concepts of pathogenesis (Review). Int J Mol Med 24: 283-293, 2009.

3. Bock O, Yu H, Zitron S, Bayat A, Ferguson MW and Mrowietz U: Studies of transforming growth factors beta 1-3 and their receptors I and II in fibroblasts of keloids and hypertrophic scars. Acta Dermatol Venereol 85: 216-220, 2005.
4. Chin GS, Liu W, Peled Z, Lee TY, Steinbrech DS, Hsu M and Longaker MT: Differential expression of transforming growth factor-beta receptors I and II and activation of Smad 3 in keloid fibroblasts. Plast Reconstr Surg 108: 423-429, 2001.

5. Al-Attar A, Mess S, Thomassen JM, Kaufmann CL and Davison SP: Keloid pathogenesis and treatment. Plast Reconstr Surg 117: 286-300, 2006.

6. Robles DT, Moore E, Draznin M and Berg D: Keloids: Pathophysiology and management. Dermatol Online J 13: 9, 2007.

7. Bayat A, Arscott G, Ollier WE, Ferguson MW and McGrouther DA: 'Aggressive keloid': a severe variant of familial keloid scarring. J R Soc Med 96: 554-555, 2003.

8. Mustoe TA, Cooter RD, Gold MH, Hobbs R, Ramelet AA, Shakespeare PG, Stella M, et al: International clinical recommendations on scar management. Plast Reconstr Surg 110: 560-571, 2002.

9. Jagadeesan $\mathrm{J}$ and Bayat A: Transforming growth factor beta (TGFß) and keloid disease. Int J Surg 5: 278-285, 2007.

10. Assoian RK, Komoriya A, Meyers CA, Miller DM and Sporn MB: Transforming growth factor-beta in human platelets. Identification of a major storage site, purification and characterization. J Biol Chem 258: 7155-7160, 1983.

11. Lee TY, Chin GS, Kim WJ, Chau D, Gittes GK and Longaker MT: Expression of transforming growth factor beta 1,2, and 3 proteins in keloids. Ann Plast Surg 43: 179-184, 1999.

12. Sadick H, Herberger A, Riedel K, Bran G, Goessler U, Hormann K and Riedel F: TGF- $\beta 1$ antisense therapy modulates expression of matrix metalloproteinases in keloid-derived fibroblasts. Int J Mol Med 22: 55-60, 2008.

13. Butler PD, Longaker MT and Yang GP: Current progress in keloid research and treatment. J Am Coll Surg 206: 731-741, 2008.

14. Massague J: TGFbeta signaling: receptors, transducers and Mad proteins. Cell 85: 947-950, 1996.

15. Bettinger DA, Yager DR, Diegelmann RF and Cohen IK: The effect of TGF-beta on keloid fibroblast proliferation and collagen synthesis. Plast Reconstr Surg 98: 827-833, 1996.

16. Polo M, Smith PD, Kim YJ, Wang X, Ko F and Robson MC: Effect of TGF-beta on proliferative scar fibroblast kinetics. Ann Plast Surg 43: 185-190, 1999.

17. Hernandez A and Evers BM: Functional genomics: clinical effect and the evolving role of the surgeon. Arch Surg 134: 1209-1215, 1999.

18. Ignotz RA and Massague J: Transforming growth factor beta stimulates the expression of fibronectin and collagen and their incorporation into the extracellular matrix. J Biol Chem 261: 4337-4345, 1986.

19. Overall CM, Wrana J and Sodek J: Independent regulation of collagenase, 72 kd-progelatinase, and metalloproteinase inhibitor (TIMP) expression in human fibroblasts by transforming growth factor-beta. J Biol Chem 264: 1860-1869, 1989.

20. Border WA, Okuda S, Langiuno LR, Sporn MB and Ruoslathi E: Supression of experimental glomerulonephritis by antiserum against transforming growth factor beta 1. Nature 346: 371-374, 1990.

21. Castilla A, Prieto $\mathrm{J}$ and Fausto N: Transforming growth factor beta and alpha in chronic liver disease. N Engl J Med 324: 933-940, 1991.

22. Broekelmann TJ, Limper AH, Colby TV and McDonald JA: Transforming growth factor beta 1 is present at sites of extracellular matrix gene expression in human pulmonary fibrosis. Proc Nat Acad Sci USA 88: 6642-6646, 1991.

23. Tredget EE: The molecular biology of fibroproliferative disorders of the skin: potential cytokine therapeutics. Ann Plast Surg 33: 152-154, 1994.

24. Younai S, Nichter LS, Wellisz T, Reinisch J, Nimni ME and Tuan TL: Modulation of collagen synthesis by transforming growth factor beta in keloid and hypertrophic scar fibroblasts. Ann Plast Surg 33: 148-154, 1994.

25. Ogawa Y, Ksander GA, Pratt BM, Sawamura SJ, Ziman JM, Gerhardt CO, Avis PD, et al: Differences in the biological activities of transforming growth factor-beta and platelet-derived growth factor in vivo. Growth factors 5: 57-68, 1991.

26. Shah M, Foreman DM and Ferguson MW: Neutralisation of TGF-beta1 and TGF-beta2 or exogenous addition of TGF-beta3 to cutaneous wounds reduces scarring. J Cell Sci 108: 985-1002, 1995.

27. Bissel DM, Roulot D and George J: Transforming growth factor beta and the liver. Hepatology 34: 859-867, 2001.

28. Derynck R and Zhang Y: Intracellular signaling: the mad way to do it. Curr Biol 6: 1226-1229, 1996. 
29. Leask A and Abraham DJ: TGF-beta signaling and the fibrotic response. FASEB J 18: 816-827, 2004.

30. Goldberg HJ, Huszar T, Mozes MM, Rosivall L and Musci I: Overexpression of the type II transforming growth factor-beta receptor inhibits fibroblast proliferation and activates extracellular signal regulated kinase and c-Jun $\mathrm{N}$-terminal kinase. Cell Biol Int 26: 165-174, 2002.

31. Yamamoto H, Ueno H, Ooshima A and Takeshita A: Adenovirus-mediated transfer of a truncated transforming growth factor-beta (TGF-beta) type II receptor completely and specifically abolishes diverse signaling by TGF-beta in vascular wall cells in primary culture. J Biol Chem 271: 16253-16259, 1996.

32. Chu Y, Guo F, Li Y, Li X, Zhou T and Guo Y: A novel truncated TGF-beta receptor II downregulates collagen synthesis and TGF-beta I secretion of keloid fibroblasts. Connect Tissue Res 49: 92-98, 2008
33. Centrella M, Casinghino S, Kim J, Pham T, Rosen V, Wozney J and McCarthy TL: Independent changes in type I and type II receptors for transforming growth factor beta induced by bone morphogenic protein 2 parallel expression of the osteoblast phenotype. Mol Cell Biol 25: 3273-3278, 1995.

34. Mori Y, Hatamochi A, Arakawa M and Ueki H: Reduced expression of mRNA for transforming growth factor beta (TGFbeta) and TGFbeta receptors I and II and decreased TGFbeta binding to the receptors in in vitro-aged fibroblasts. Arch Dermatol Res 290: 158-162, 1997. 